St. Catherine University

From the SelectedWorks of Hui Wilcox

2019

\title{
Global and local media and the making of an Ethiopian national icon
}

Hui Wilcox, St. Catherine University 


\section{Global and local media and the making of an Ethiopian national icon}

\section{Hui Niu Wilcox}

To cite this article: Hui Niu Wilcox (2019) Global and local media and the making of an Ethiopian national icon, Journal of African Cultural Studies, 31:3, 385-401, DOI: 10.1080/13696815.2018.1546168

To link to this article: https://doi.org/10.1080/13696815.2018.1546168

曲 Published online: 15 Nov 2018.

Submit your article to this journal $\pi$

III Article views: 82

View Crossmark data $₫$

Citing articles: 1 View citing articles 


\title{
Global and local media and the making of an Ethiopian national icon
}

\author{
Hui Niu Wilcox \\ Department of Sociology, St. Catherine University, St. Paul, MN, USA
}

\begin{abstract}
This paper analyzes the global and local media coverage of Melaku Belay, an acclaimed Ethiopian dancer and social entrepreneur. How have the media mythologized his story? How does Melaku participate in the mediated narration of his life? I address these questions by historically situating Melaku's biography and by juxtaposing media representations with my interviews with the artist and observation of his performances. This inquiry illuminates the signifying power of Melaku's masculine dancing body for both neoliberal ideology and Ethiopian nationalism. The media have rendered Melaku's story into a myth that promotes the neoliberal ethos valorizing private ownership. Melaku, however, remains agential by selectively engaging with the media, and by sharing his own vision of nation and self. These layered analyses illuminate the complex relationship between agency and representation in the contexts of neoliberalism/neocolonialism, nationalism, and globalization.
\end{abstract}

\section{KEYWORDS}

Media representation; neoliberalism; Ethiopian nationalism; Ethiopian dance; African performance

Melaku ${ }^{1}$ Belay is an Ethiopian legend in the making, known as 'the King of Eskista' for his creative performance of traditional Ethiopian dances. Eskista, the most well-known dance form associated with Ethiopia, refers to the rhythmic movement of the shoulders, most commonly seen in the highland traditions of northern Ethiopia. Melaku's virtuosity, however, goes well beyond eskista. According to his website (melakubelay.com), Melaku has mastered 'no less than 30 different dances' of Ethiopia. He regularly performs dances of Amhara, Gurage, Oromo, Wolayta, Tigray, Agew and Kunama with two groups that he established in 2009. The larger group Ethiocolor involves six Ethiopian instruments - one masinqo (string), two krars (string), two sets of drums, one washint (flute), two vocalists and four dancers (two men and two women). Based in Addis Ababa, Ethiocolor performs bi-weekly in Fendika, a small music club drawing local and international audiences (Figures 3 and 4). Fendika is also the name of Melaku's smaller band (with three instrumentalists, one vocalist and two dancers) that tours internationally. Ethiocolor and Fendika perform original choreographies for the stage, although the melodies and movements are recognized as 'traditional'. In a typical concert, the dancers are positioned front and center of the stage, with the musicians forming a half circle behind them. Dancers wear ethnic clothings corresponding to the dances (for Gondar Amhara dance for example, 
white knee-length shirts and pants for men and white floor-length dresses for women). Even though Melaku performs with other talented dancer(s) and the best musicians in Ethiopia, his creative and dynamic dancing is always the highlight of these concerts (Figures 1-4).

It is of little surprise that Melaku attracted media attention as soon as he started performing outside of Ethiopia in 2007. The New York Times dance critic describes his 2011 Lincoln Center performance at length (https://www.youtube.com/watch?v=qwWpXSsBDxY):

[T]he rhythmic virtuosity of Mr. Melaku was often astounding. He can turn either the upper or the lower body into an electrifying vehicle of rapid pulsation.... In later dances he showed how he could play his shoulders, his neck, his head and his whole torso like percussion instruments. In one number his shoulders kept chiming in like chords in music.... At the climax of one amazing dance cadenza, his own body became a trill - initiated, it seemed, from somewhere around the diaphragm and midspine, but with the whole body shaken into a blur ... All these were dazzling bravura touches. Mr. Melaku's dancing, however, didn't consist just of stunts. Simply to see him sway his body to the music was a marvel: the angle of his outheld elbows, the pliancy of his spine, the rhythmic point of those shoulders all made their sensuous contributions. A happily superlative artist. (MaCaulay 2011)

Most of the media coverage of Melaku, however, centers on his biography and entrepreurship. The traditional music club Fendika Azmari Bet that Melaku owns was featured in The New York Times (Doyle 2014), Australian Broadcast Corporation (2015), and The Guardian (Gordon 2016). In Ethiopia, Melaku has appeared in numerous print media as well as on radio and TV. His life is the subject of an hour-long documentary Melaku (2014).

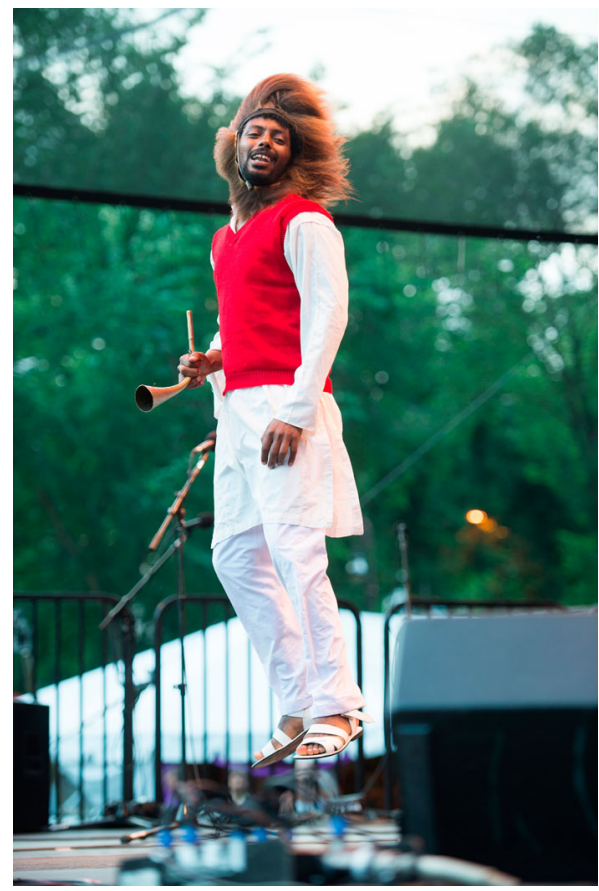

Figure 1. Melaku performing Oromo Dance, Photo by Mario Di Bari. 
Media discourses play a dialectical role in the rise of cultural icons: more than merely reflecting reality, they also construct reality (Bail 2012; Gamson et al. 1992). In this paper, I analyze media content pertaining to Melaku to illustrate how the media appropriate his narrative to bolster the myth of neoliberal individualism. Roland Barthes (1991) defines myth as a political speech that justifies social orders. 'Myth is constituted by the loss of the historical quality of things: in it, things lose the memory that they once were made' (Barthes 1991, 142). Myth then can be 'deciphered' through reclaiming complexity of history, memory and biographies. I use interview and ethnography to historically situate Melaku's biography, and to understand his perspectives on the mediated narration of his story. This inquiry contributes to the growing media research in Africa, by shedding light on the complicated relationship between media representation and the agency of those represented. In Melaku's case, his agency is both compromised and enhanced by the media. While he cannot control how the media tell his story, he has also benefited from the reality that the media have helped create: Melaku is now a national icon, whose masculine dancing body stands for neoliberal governmentality as well as Ethiopian nationalism.

I situate this inquiry in the broader project of decolonizing discourse and dance in Africa. Ethiopia's encounter with European colonization warrants careful consideration instead of facile dismissal based on the oft-cited fact that Ethiopia has never been colonized. Ethiopia avoided systematic colonization through relentless anti-colonial struggles, both in its elite-led form symbolized by the Battle of Adwa in 1896 and in the form of grassroot resistance against the Italian occupation (1936-1941). Scholars (Giorgis 2012; Smith 2013) argue that despite the absence of colonial rule in Ethiopia, the project of Ethiopian

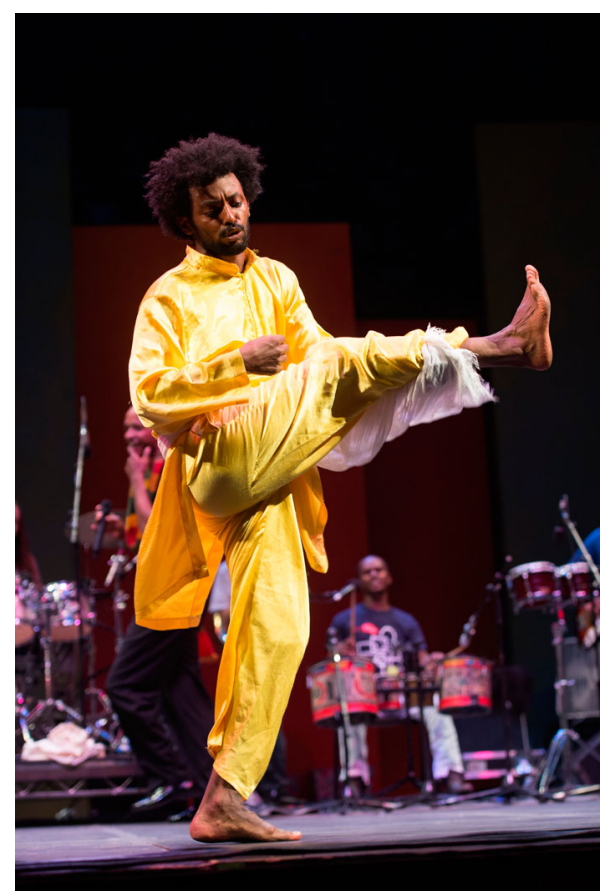

Figure 2. Melaku performing Gurage Dance on a Concert Stage, Photo by Mario Di Bari. 


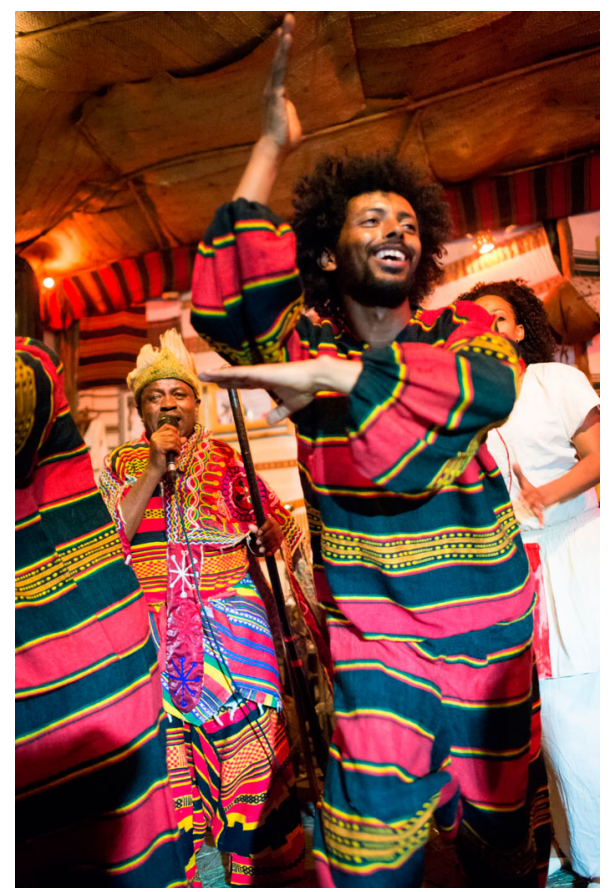

Figure 3. Melaku performing Wolayta Dance in Fendika Azmari Bet, Photo by Mario Di Bari.

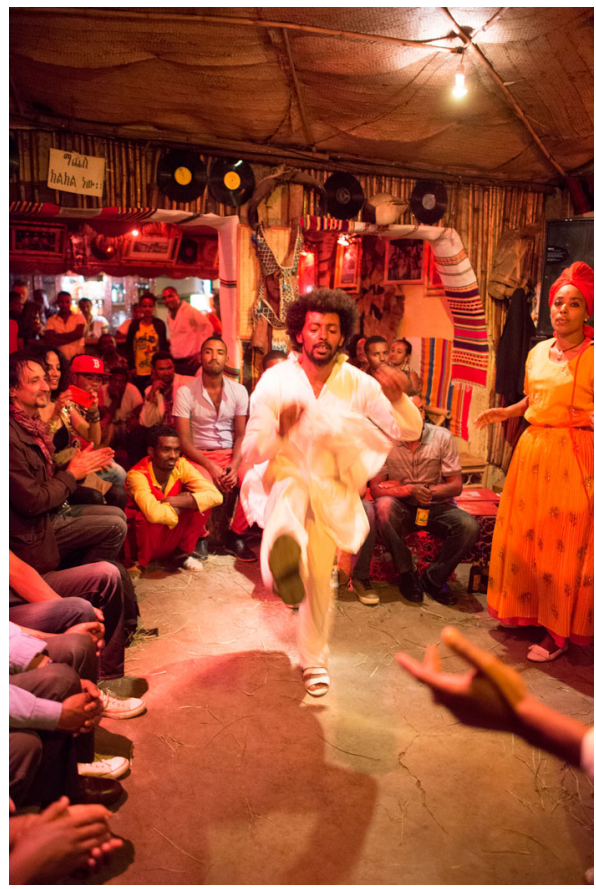

Figure 4. Melaku performing Gurage Dance in Fendika Azmari Bet, Photo by Mario Di Bari. 
modernity has taken place in the historical context of African colonization, decolonization, and neocolonial domination. Media representations pertaining Ethiopia are necessarily embroiled in colonial discourses about Africa and Africans in general. These discourses still frequently portray Africans as victims of poverty, famine, diseases, and dictators (Keim 2009; Weiner 2016). Africa remains the 'dark continent' against which Westerners claim their own cultural and 'racial' superiority. These accounts often erase or downplay the significance of colonization, and attribute the contemporary under-development of African nations to the incompetency of their own governments, natural disasters, or Africans' lack of autonomy.

I challenge the persisting narrative of 'Africa as victim' that dominates the Western imagination (Steeves 2016), by examining the construction of Melaku's story and tending the gaps and contradictions that surface in different media sources. Drawing inspiration from African performance studies (Drewal 1991), I argue that a study of media representation of public figures should consider not only media texts and images, but also these figures' voices and embodied performance. By scrutinizing multiple forms of texts - words spoken and printed, performance on and off stage - in relationship to each other and in their social and historical contexts, I make explicit the ambiguity and complexity of constructed realities.

\section{Neoliberalism, nationalism, and local norms}

Melaku's celebrity status testifies to his ability to accrue some cultural and economic power in Ethiopia. In the late 1990s, there were seventeen traditional music clubs in central Addis Ababa, where Melaku's Fendika Azmari Bet is located. Now Fendika is the only one remaining. However, Melaku's agency must also be seen in its context: His benign, masculine persona has been appreciated as a potent symbol partly because of the patriarchal nature of Ethiopian society (Konjit 2006; Poluha n.d.; Smith 2013). His fame was in part spurred by European and American recognition of his talent in both dance and entrepreneurship. Furthermore, his entrepreneurship is both enabled and constrained by neoliberal globalization as well as Ethiopian state policies of development and urbanization.

Since the early 1990s, the Ethiopian state has focused on neoliberal economic development while trying to manage the nation's complex ethnic politics. Contemporary Ethiopian nation- and state-building is entangled with neoliberal globalization, as the current regime relies on international donors and institutions such as International Monetary Funds to implement development goals. The Ethiopian state attempts to resolve historical problems of ethnic tension through ethnic federalism, a system where federated units are defined along ethnic lines. The Ethiopian Constitution of 1995 granted ethnically-based regions some degrees of autonomy. Applauded by some for granting rights to previously marginalized groups, ethnic federalism has been criticized for potentially disuniting the nation, as citizens' heightened ethnic identities might weaken their identification with Ethiopia and strengthen centrifugal forces of ethnic nationalisms (Assefa 2012; Sorenson 1993; Turton 2006; Zahorik 2011).

In addition to competing nationalisms, local cultural factors might also affect neoliberal processes. In an ethnography about young men's unemployment in Jimma, Ethiopia in the late 1990s, Mains (2012) observes that norms regarding masculine respectability 
prevented working-age young men from seeking work in the service industry, ironically one of the sectors that are stimulated by neoliberal capitalism. By placing Melaku's story in these contexts, this paper reclaims the complexity and historicity of Melaku's biography, and reveals the processes and effects of media myth-making.

\section{Methodology of compassion}

Methodology is storied, as it accounts for who we (the researchers) are, who our subjects are, how we have come to the research, and why we research the way we do. I am a Chinese-born American sociologist who also maintains an active dance career. In 2015, I participated in an international art festival in Addis Ababa as part of a U.S.-based women-of-color dance company. We took our first group photo on a busy street; in the blurred background was a beer advertisement that covered the entire façade of an 8story building. Little did we know that the face in that advertisement belonged to Melaku, who, a few days later, introduced himself to us as a 'traditional dancer'. He invited us to Fendika, the traditional music club that he owns. Although I was in Ethiopia as a member of a dance company, the sociologist in me was at work, too. I am intrigued by the many contradictions that Melaku embodies: a celebrity who is self-effacingly humble, a free-spirited artist who is also a savvy entrepreneur, a master of traditional dances who improvises wherever he finds rhythm. A globe-trotting artist, Melaku proclaims a deep love for Ethiopia, vowing to always return home ('Building Bridges' 2012).

Shortly after our sojourn in Addis Ababa, I contacted Melaku to ask if I could write about the media's telling of his story. He generously agreed. In 2016 and 2017, I began media research and interviewed him in New York and Minneapolis. 2018 brought opportunities for me to visit Fendika as an ethnographer for two weeks and to work with Melaku and Fendika's touring musicians during their month-long U.S. tour. I conducted interviews and ethnography not with the illusion that I would know the 'real' story of Melaku, but with the hope that qualitative research will shed light on the complexities and historicity of his stories.

As I try to decipher neoliberal and nationalistic myths around Melaku's story, I struggle to avoid myth-making of my own. How do I re-present his story without its re-mystification? Reckoning with that struggle and the impossibility of complete knowledge, I propose a 'methodology of compassion'. Melaku is a complex person with a history prior to the interest by the media and researchers (myself included). The media do not attempt to capture the fullness of his story; in fact, I will argue that the media intentionally eclipse this fullness so that Melaku's life becomes a mere signifier for neoliberalism and nationalism. A methodology of compassion acknowledges that I do not know the full story of Melaku, but it requires that I grapple with the 'historical quality' of his story (Barthes 1991). In so doing, I practice compassion towards not only Melaku, but also to all other knowledge producers (myself, my readers, and authors of media content), as we are all human beings possessing only partial knowledge. Practically speaking, a methodology of compassion entails mindful, reciprocal practices. I am aware of my position of power as a researcher of the North, and I am humbled by my ignorance about Ethiopia to begin with. During the last three years, I delved into the literature about Ethiopian history, society, and dance; I also started learning Amharic, the working language of Ethiopia. Melaku is a co-producer of knowledge who participates in this project in multiple ways: 
not only did he grant me interviews and access to Fendika, but he also read drafts of the paper.

Methodology of compassion asks that we engage in multiple ways of knowing. I saw Melaku and his ensembles perform live in Ethiopia and the U.S. multiple times between 2015 and 2018. I have also watched and analyzed YouTube videos of their performances. This research urges a re-assessment of content and discourse analysis. These text-focused methods, paying attention to latent meanings in written language's gaps and silences, aim to reveal the underlying ideology or power dynamics of constructed representations (Mills 1997/2004). But wouldn't we discern even more gaps and silences - more opportunities for meaning making - if we juxtapose multiple modes of representation and performativity?

\section{Overview of media data}

I utilized Melaku's website to collect media data (melakubelay.com) up to 2014, but have collected the most recent data through my own research. The media data for this paper consists of 38 articles, 8 TV interviews, and 6 radio programs, dated from 2007 to 2017. Of the 38 articles, 17 are Ethiopian sources, 8 American, and 13 European. Of the first 12 articles about his work (December 2007-September 2010), 8 of them are European sources, 2 Ethiopian, and 2 American. Among the next 12 articles (September 2010-May 2013), 7 are Ethiopian sources, 3 European, and 2 American. The most recent 14 articles (July 2013-November 2017) include 7 Ethiopian sources, 6 American, and 1 European.

Both local and global media have contributed to the growing reputation of Melaku. The initial report was by a European blogger (Counterfnord) in 2007, as Melaku began his touring career in France. The attention in Europe peaked in 2010 (with 6 articles). The same year also witnessed an increased interest by the U.S. media, as Melaku's band Fendika made their U.S. debut. The Ethiopian media have increased their coverage of Melaku over the years, and the proportion of domestic versus global coverage has grown over time. Keeping in mind the messy negotiation that leads to the production of media content, I focus on the recurring narrative themes in the data, and how neoliberal globalization and Ethiopian nationalism inscribe Melaku's story. I also read these texts with a keen awareness that Melaku's dancing body also writes history and claims agency (Drewal 1991).

\section{'Historical quality of things'}

\section{Melaku's story - a sketch}

Melaku was born in Addis Ababa in 1980, to a single mother. Three years later, his mother left for Sudan as a refugee, leaving Melaku to the care of relatives, one of whom he referred to as 'mother' in his biographical documentary. Melaku quit school after attending 9th grade when his foster mother fell ill (Documentary Melaku 2014). After her passing, Melaku lived on the streets for a few weeks ('Meet Melaku Belay' 2013). His website indicates that he started dancing in Fendika in 1997. From 1997 to 2007, he performed nightly in Fendika. For the first seven years, he slept under the bar in Fendika and studied there to complete his 12th-grade education: 'I took full responsibility for my own food, school fees, 
clothes, books ... etc. I remember how I felt when I finished high school ... I felt as if I earned my Ph.D.' ('Meet Melaku Belay' 2013). In 2006, a friend invited him to dance at Alliance Ethio-Francaise, a French NGO in Addis Ababa (Documentary Melaku 2014). Soon he began teaching dance lessons and touring internationally. He became Fendika's manager in 2008, and took over its ownership in 2015. Managing Fendika has since consumed much of Melaku's time. He still performs as a dancer, but mostly for touring and special weekly concerts.

I constructed this narrative using multiple sources: print media, social media, online videos, documentary films, and my own interviews with Melaku. As much as I tried to be 'objective', what I know is shaped by the media, and by what Melaku chooses to share with me.

\section{Melaku's story through historical lenses}

The story I just outlined does not reflect the fullness of Melaku's life. Not knowing all the details does not prevent us from the work of demystification, if we are able to historicize biographies. Thus I proceed to correlate Melaku's life events with noted historical events of Ethiopia. The year 1974, shortly before Melaku was born, saw the overthrow of the imperial government by the Marxist regime known as the Derg. In the decade that followed, Ethiopia witnessed unprecedented mass emigration (Pankhurst 1992). The story of Melaku's mother leaving him behind to flee to Sudan was not uncommon, as '[b]y early 1980s, an estimated 2 million Ethiopians had left their country for the neighboring countries, mainly Sudan', 'either because of the Derg's highhanded rule or as the result of the bloody rivalry between the various political groups and guerrilla movements' (Solomon 2007, 101). Being orphaned is experienced by many children in Ethiopia, even today. However, the meaning of orphanage has to be understood in that specific context: orphaned children in Ethiopia are often not alone, as Westerners tend to understand; they are sometimes taken care of by relatives, and often supported by a network of family, neighbors, friends, and increasingly, NGO workers (Heinonen 2011; Nieuwenhuys 2001). Melaku, for example, benefited from a devoted caretaker for most of his childhood, 'who taught me I can be who I want to be if I don't give up' (Documentary Melaku 2014).

Melaku acquired his early education through the Derg's system. In the documentary Melaku, the grown and famous Melaku walks among the kids in a sun-lit school, recounting memories of singing his favorite songs as a school kid. But he also speaks of having to take care of eight cows, and of feeling embarrassed because other kids shunned him due to his smell. The sting of poverty, for Melaku, seems to be mitigated by living in a Marxist regime that aspired to universalize education. However embarrassed the young Melaku was by his poverty, being impoverished did not destroy his spirit. His survival and eventual success can be attributed to both personal resilience and social contexts: his passion for music and dance was nurtured by rich performance traditions in Ethiopia, which persisted even during the Derg rule.

Melaku's experience during the Derg era contradicts the Western imagination of the 1980's Ethiopia (Solomon 2007). The Cold War ideology has people convinced that life under communist regimes is nothing but bloodsheds and oppression. The Australian Broadcasting Corporation radio (2015), for example, declares that all music was prohibited by the Derg. However, judging from the documentary Under African Skies: Ethiopia (1984), 
Addis Ababa in the 1980s, despite the oppressive Derg rule, was lively with music and dance both in commercial and private settings. Many of the musicians featured in the film were claimed by Melaku as his musical influences (Romero 2015).

The years between Melaku's loss of his foster mother and his arrival at Fendika corresponded with a major historical shift of the nation. In 1991, when the Derg was toppled by the EPRDF (Ethiopian People's Revolutionary Democratic Front), Melaku was entering his adolescent years. Soon he would struggle with family illness, drop out of school, and spend time on the street. Heinonen (2011)'s ethnography of street children in Addis Ababa in the 1990s reveals a world of poverty, struggles, and hopelessness. But she also notes the resilience and compassion of these youngsters, somehow managing to survive and take care of each other. Her research also shows the gender dimension of street life in Ethiopia: while both boys and girls suffer from hunger, sickness, and exposure to the elements, girls are much more susceptible to violence.

Melaku's adolescent years witnessed the post-socialist transition of Ethiopia, the onset of ethnic federalism, and neoliberal privatization (Ferguson 2006; Mains 2012). Western influence has flooded Addis Ababa in the forms of non-governmental organizations and aid agencies since the 1990s. It was a time of transformation, both for Melaku as a young man, and for Ethiopia as a nation. The social condition of turmoil and violence associated with regime change likely made his life difficult (Solomon 2007), but new opportunities also opened up. Addis Ababa was developing fast, becoming known again for its bustling night life. Music clubs featuring traditional Ethiopian music and dance mushroomed. In the late 1990s, there were 17 of them in one neighborhood, Kazanchis. It was in one of these places, Fendika, where Melaku launched his dance career.

The turning points of Melaku's life coincided with political and economic transitions of the nation. He was born during the communist regime and came of age when the new government embraced liberal economic policy and ethnic federalism. For many Ethiopians, the combination of these two forces have been socioeconomically alienating and culturally divisive. Having spent his formative years when national unity was the dominant ideology, Melaku identifies with a unified Ethiopian nation. Ethiopian unity is a historical construct that has been extolled through mythological representations of emperors/warriors, Orthodox Christianity, and the Amharic language (Zahorik 2011). For Ethiopians invested in this construct, consciously or otherwise, Melaku possesses many qualities of a cultural icon: his male, Amhara, Christian identity, his triumphs over life's hardships, his ability to master more than 30 different ethnic dances, and his love for Ethiopia.

\section{Neoliberal myth-making: erasure, uniformity, hyperboles, and stereotypes}

Having situated Melaku's story in recent Ethiopian history, I now examine how the media tell his story, and for what ideological purposes. Addis Fortune, an Ethiopian business weekly, wrote about Melaku's life story in 2009:

He worked his way up from being a street kid who could dance, to dancing for nine years at Fendika earning only tips, to owning it as well as dancing and working with many musicians from countries all around the world. ('Astounding Azmari Bet Strikes' 2009)

The mystified story of Melaku is necessarily broad-stroked, featuring a beginning (being a street kid), a middle (dancing for nine years at Fendika earning only tips), and an end 
(owning Fendika, working with musicians from all around the world). It begins with a description of circumstances that rouses curiosity: What does it mean to be a street kid in Addis Ababa? Homelessness? Delinquency? Such ambiguity leaves space for the projection of Western fantasies about a menacing 'third-world' place and the potential of a masculine subject. The middle of the story offers selective details of Melaku's early struggles in Fendika, so that the reader can empathize with him and cheer him on. The ending signifies progress and hope. The media, in and outside Ethiopia, revel in Melaku's entrepreneurial feat, often ending the story with 'now he owns Fendika', for indeed, private ownership would be the happy ending of any story in a perfect neoliberal world (Harrison 2010). Since it is a hopeful, satisfying ending, there is no need to learn about Melaku's continuing struggles as an artist and a small business owner. Furthermore, although many young men in Ethiopia are unemployed and do not feel hopeful (Mains 2012), such historical reality is hardly the concern of the Western media. Underlining this ahistorical tale is the familiar teaching that through hard work, success is possible even for those in the most humble circumstances. Neoliberal governmentality as a regime of truth obtains a 'universal' status, as all self-made stories are framed within a uniform structure regardless of time and place.

In 2010, Czech writer Petr Doruzka published his interview of Melaku as a blog. Upon declaring 'His life stories are shocking', Doruzka relayed Melaku's first-person account:

'I lived here ... for seven years, sleeping under the bar,' says the ever-smiling and energetic Melaku. 'During the dictatorship, when I was three years old, my mother went into exile in Sudan and ended up in a refugee camp. I became a street kid. I grew up with my cousin, who is older, but fell ill and died.... I lived on the street since my childhood and danced, and together with my friends, we did dance projects.... Once I learned that Fendika needed a dancer. I asked them if I could live here... So I came in and danced, and they embraced me. I did not get a salary, only tips from guests.... I still lived with street children, and when I gained confidence, I bought a mattress and began to sleep under the bar. I worked at the club at night, gave dance lessons at the theater during the day, went to night school in the evening, and finished my high school education that way.'

Compared to the story in Addis Fortune, Melaku's own account is much more detailed. In this telling, even as a street kid, he had a sense of community and had people who care for him: his foster mother, friends who danced with him, and people of Fendika who embraced him. When a French newspaper Le Point picked up this story, those relationships disappeared:

Near Addis Ababa during the Communist period of Derg (1975-1991), Melaku saw his family flee the 'Red Terror' towards Sudan. He stayed in his native capital. Alone. Barely a teenager, he dropped out of school to give himself entirely to dance.... At 18, he became a dancer at Fendika.... He accumulated tips at night, and made pocket money by giving lessons during the day. 'For seven years, I did not have a salary. I slept behind the counter. I almost left everything behind to become a taxi driver,' he explained. But the kid from the street did not give up. Never. ('Watch Melaku and Zinash' 2014)

\section{A similar narrative appeared in The New York Times in 2014:}

The self-taught dancer, who is 38 , had first come to the place where the Ethiocolor Band performed when he was a child living on the street. Mr. Belay said that he'd slept under the bar for seven years, earning his board by working without pay. Many years later he bought Fendika Azmari Bet from its former owners and began to shake up the city's cultural life. (Doyle 2014) 
In contrast to Melaku's own story-telling that accounts for social relationships, these sources emphasize Melaku's struggles against life's odds alone and his achievements through hard work and will power. Offering no historical context, The New York Times article identifies Melaku as 'the self-taught dancer' and solely focuses on his individual merit, thus fashioning him into yet another self-made neoliberal success.

Instead of erasing history completely, the French newspaper hijacks history to design a set where Melaku emerges as a heroic figure who faces a cruel world all by himself. 'Melaku saw his family flee the 'Red Terror' towards Sudan. He stayed in his native capital. Alone'. These sentences make it sound as if the three-year-old Melaku chose to stay in Ethiopia, despite the 'terror' that his family fled from. In this passage, we find recurring examples of what Barthes calls 'excessive language' of myth-making (Barthes 1991, 160). 'He stayed in his native capital. Alone'. And then, 'But the kid from the street did not give up. Never'. These emphatic sentences effectively convey the odd-defying power of Melaku the lone street kid.

Familiar narrative structures, erasure of history, and hyperboles are just some of the tools of neoliberal myth making. And these were the same discursive mechanisms that consolidated colonial stereotypes, deep-seated in the Western consciousness (Said 1994). A colonial undertone can be detected in these neoliberal descriptions of Melaku in the Western media: 'a happily superlative dancer' (MaCaulay 2011), 'ever smiling and energetic' (Doruzka 2010), and 'Discreet and humble, he never stops smiling' ('Watch Melaku and Zinash' 2014). Cited repeatedly, colonial stereotypes turn the colonized body into a screen on which the West projects its ideas of the 'Other' (Bhabha 1997). Discursively fixing Melaku's smile as a constant to the colonial and neoliberal/neocolonial gaze, these accounts deprive Melaku of emotional complexity.

The ever-happy figure of Melaku the African dancer serves to preempt inquiries of his relationship with the West, and of his location in Ethiopia's class, gender, and ethnic structures. My interviews and observation have shown that Melaku celebrates Ethiopia's anticolonial struggles and is critical of neocolonial practices in Ethiopia. When he spoke to a group of college-educated activists in Addis Ababa in 2018, he challenged their exclusive use of Engligh in conducting their meetings. The media's silence about Melaku's complicated relationship with the West is consistent with their reluctance to investigate the colonial dynamics in Euro-American consumption of African cultural artifacts as well as practices.

Media accounts that love to spotlight Melaku's upward mobility also say nothing about the actual class structure in Ethiopian society. In the late 1990s, when Melaku came of age, Ethiopia's unemployment rate was nearly 50\% (Mains 2012). Many educated young men were unemployed because they could not find government jobs, made scarce partly by Ethiopia's neoliberal structural adjustment. Melaku knew the importance of education, as he 'felt guilty about quitting school' ('Meet Melaku Belay' 2013) and completed high school while working as a dancer, harboring dreams of a better life just like other Ethiopian young men. What sets Melaku apart, is his choice to follow his passion for dance, even though it falls in the realm of entertainment and service, accorded with low status and little respect (Mains 2012). Omitting these contextual factors of Melaku's life, the media's storytelling reiterates the neoliberal logic, according to which historical and socioeconomic contexts are much less relevant than individual aspirations and effort. The 
underlying message is the universality and naturalness of neoliberal principles (Harrison 2010).

The ethos of individualism is also accented in a British account where Melaku is described as a 'maverick', who claims that he was born dancing ('Impromptu Addis' 2013). The connotation of the word 'maverick' is not only individualistic, but also masculine and aggressive. It is not so far-fetched to posit that Melaku's masculinity has contributed to his upward mobility, probably starting early on in his life. Heinonen's (2011) study of street children in Ethiopia demonstrates that boys have much more freedom than girls in establishing social networks beyond the domestic sphere. Melaku's ability to tour the world with a Dutch punk band would have been unimaginable for an Ethiopian woman artist. When he began organizing his own tours in 2009, he invited women artists right away - notably dancer Zinash Tsegaye and singer Nardos Tesfaw. Extraordinary artists who have toured extensively with Melaku, Zinash and Nardos have received little attention from the media.

\section{'I'm Ethiopian. That's all.'}

Another dimension of Melaku's story that journalists have glossed over or omitted is the creative tension between Melaku's independent spirit and his community-centered practice of dance. Although Melaku savors the image of a naturally talented dancer, he credits the street festivals of Addis Ababa for teaching him how to dance. And he has made his life's mission to give back to the people of Ethiopia (Interview 2016). The local and global media have appropriated Melaku's story to universalize neoliberal governmentality, but he did not leave his story to be told only through the media's neoliberal lenses. Having grown up during the Derg that called for national unity and experienced growing ethnic tension in the post-socialist era, he is critical of ethnic federalism and champions a version of Ethiopian nationalism that extols unity and embraces diversity. During a 2017 interview about his 'ethnicity', he declined to comment, and said, 'I'm Ethiopian. That's all'. Melaku proudly claims to 'represent Ethiopia' when he tours abroad. A 2018 Fendika concert in Minneapolis (https://www.facebook.com/Zehabesha/videos/326676191441490/) opened with a Kunama dance, followed by Oromo, Agew, Tigray, Gurage, and Amhara dances. This format is reminiscent of socialist-era state-sponsored performances such as People-toPeople, Ethiopia (1987) (https://www.youtube.com/watch?v=kgrdly0KxLU).

The relationship between dance and nationalisms in Ethiopia deserves much more discussion than I have space for here. Suffice it to say that Melaku's embodiment of many ethnic dances has been a source of contestation, as most people identify him as Amhara despite his own reluctance to claim an ethnicity. An Oromo viewer of his 2018 Minneapolis concert commented on the livestream video, 'We need [the] original not [a] copy'. In a 2018 interview, Melaku speaks about his own perspective on dance and ethnicities: 'We speak more than 60 languages, [but] we are one. When I hear Oromogna [music], I dance, I jump. Even though I don't understand the language, I understand the energy, the history'.

The sentiment behind this statement is consistent with what emerges from my own interviews and observation. Melaku's love for Ethiopia is rooted in his embodied experience of Ethiopian culture: peoples, places, music, and dance. He has yet to fully investigate the idea of nations as mythological constructs, but he understands the state does not 
represent the nation. He also understands that he needs to work with the government's stipulations to survive as an independent artist and a small business owner (Interview 2018). Somehow finding a place for himself in this state-nation-society nexus, Melaku accepts the responsibility that comes with being a cultural icon of Ethiopia. The following passage comes from Addis Ababa-based Eminence Magazine's 2015 feature about Fendika:

The message Melaku sends to young and struggling artists in the country ..., 'If you have a vision, stay strong for that vision'. As a young artist who spent 10 years sleeping under Fendika's bar, performed without getting paid, and openly shares about the hard and good times of his life, he believes, 'What is important is to keep the dream and stay strong'. (Haewon 2015)

Speaking inspirationally to 'young and struggling artists in the country', Melaku exercises his power to influence Ethiopian society. He consciously crafts his story as a moral lesson for the country's youths. In a recent interview (2017), Melaku discloses that he screens media requests for interviews and turns down those that exclusively focus on his personal life. He agrees only to those interviews that he thinks 'can benefit society'.

The ethics that Melaku expresses here resonates with his quote in the documentary Melaku, 'When one helps himself, he helps the nation as well'. The statement, referring to a masculine national subject (he/himself), appeared twice in the documentary, at the beginning and the end. The last part of the film takes the viewer into his home, a cramped room with a cabinet of neatly arranged cassette tapes, a pair of socks hanging to dry on the side of the cabinet, a single bed, and a small window. It appears to be a modest home of a young man who takes care of himself. The camera focuses on the suitcase that Melaku prepares for the first overseas tour of his own band Fendika. He packs an Ethiopian history book. He unlocks a drawer, finds his passport and carefully places it in the suitcase. In another scene, he flips through his passport, showing all of his visas: 'France, Italy, Spain, Germany, America ...'

Melaku is firmly located in Ethiopia. Like many other working-class Ethiopian men, he has solved his temporal problems - of being born into poverty and experiencing economic hardship - with spatial strategies of movement (Mains 2012). But his spatial strategy is different from that of his contemporaries; it is not migration out of Ethiopia, but performing around the world and returning to Ethiopia, again and again. Thanks to a multitude of factors - structural, communal, and individual - he did not get stuck in neoliberal Ethiopia with dim prospects. He danced, traveled, and returned, in contrast to many whose only hope is to emigrate permanently. Living in Ethiopia is what his heart desires. 'I will die in my home, my country', he asserted in an interview with Addis Rumble ('Building Bridges' 2012). Indeed, staying in Ethiopia can be instrumental for him. If he lives in the West, the chances of his becoming an influential icon are slim: His expertise is rooted in traditional Ethiopian dances and his most powerful performances take place in Ethiopia, where audiences are most understanding and responsive. The strategy of emigration would not have served him well, whereas, based in Addis Ababa, he has earned the reputation of 'cultural ambassador of Ethiopia'.

The scene of Melaku packing and showing his passport is highly performative. As his packed suitcase and tattered passport signify his mobility, Melaku becomes a sign for the aspiration of Ethiopian culture and nation - masculine and mobile, shaking up the stage and the world with his dance. It is an inspiring story, but in the end, there is only one Melaku whereas many Ethiopian youths are still facing uncertain futures and 
dreaming of an American or European visa. Aware of this reality, Melaku considers his cultural work a possible contribution to Ethiopia's socio-economic problem: 'If people are proud of our culture and identity, they will not run away' (Interview 2016). Dance and music making, to Melaku, is how he fulfils his civic responsibilities towards Ethiopia.

\section{Constrained agency}

Based on analyses of media coverage of Melaku Belay, ethnographic observation and interviews, I have illustrated the media's multiple techniques in shoring up the myth of neoliberal individualism: adopting a universal narrative structure (poverty-strugglesuccess), erasing history, eclipsing class, gender and colonial dynamics, and using excessive language and stereotypes. The media, both global and local, offers a predictable tale of individual autonomy disregarding nuances of Melaku's lived experiences and their contexts. But the Ethiopian media and their Western counterparts have somewhat different priorities. The former (exemplified by The Eminence's 2015 feature) tend to capture the dual connection of Melaku's story, to the Ethiopian nation on one hand, and to neoliberalism on the other. In Ethiopia, his personal triumphs have been used to evoke national pride as well as to motivate people in their struggles for material success. Melaku readily accepts the association between his biography and Ethiopian pride and adopts the media as a platform to share his vision for the Ethiopian nation. The Western media, however, have shown little interest in Melaku's implications with Ethiopian nationalism; they are much more invested in his story as it serves neoliberal ideology.

Melaku is not a victim simply being manipulated by mediated storytelling. On the contrary, he asserts some control in the narrative. He frequently declares I'm proud to be Ethiopian'. This pride does not seem to be diminished by his adverse experiences with the Ethiopian state that constantly threatens to demolish Fendika and other small properties in order to 'develop' the capital city. Despite his frustration with aspects of Ethiopian society, Melaku has deliberately chosen to embody Ethiopian traditions, because he believes in the value of deep-rooted (and dynamic) identities in a changing nation and globalizing world. However, this aspect of his agential choice is also tampered: In today's global performance circuits dominated by the global North, artists from the South are almost always booked under the category of world music/dance, an updated code for exotic and traditional forms from the Western perspective. Melaku's border crossing is not without conditions that limit his artistic vision.

In this context where tradition and innovation are often dichotomized, Melaku tries to find nuances, consciously showcasing the innovative potential of his traditionally-based art (Romero 2015). In a 2011 short film Ahun! Performing Mercato (https://www.youtube. com/watch?v=HkMkcyouGV0), Melaku improvises with traditional Ethiopian dances such as eskista and Gurage in the largest open-air market in Addis Ababa, where the metal workers pound recycled sheet metal into large barrels. 'Most people hear noises and cover their ears. But I hear music and I want to dance' (Interview 2018). As Melaku moves his shoulders in all directions and various speeds, and kicks his legs in front of him while leaning his torso back, the cacophony of metal pounding begins to sound rhythmic. The film's introductory text informs the viewer of the Italian occupation of Ethiopia (1936-1941), when Mercato became the trading place of Ethiopians, separated from 
Italians. The text also acknowledges the cultural and aesthetic values of Mercato, and expresses concern that its existence is threatened by the development of modern shopping malls. Dressed in clean traditional clothes in contrast to the workers' stained tshirts or overalls, Melaku seems out of place in Mercato. His joyful dancing also contrasts with the workers' mundane work. But isn't dance a form of work also? Melaku does not have to dance there, but he chooses to. It was an agential act of dancing to draw attention to the historical and contemporary evolution of urban spaces in Ethiopia. The moment when a worker looks up and smiles at Melaku's dancing reveals a bit of their shared camaraderie as masculine Ethiopian bodies occupying that particular space, notwithstanding different class positions at the moment. The title Ahun! means 'Now!', referring to the moment that bridges the nation's tumultuous past and uncertain future. Melaku is a contemporary dancer with a historical consciousness.

\section{Conclusion}

I have offered a case study of negotiated agency in media representation, through a threepronged approach: historically situating Melaku's biography, deconstructing media narratives by juxtaposing modes and sources of story-telling, and heeding Melaku's own voice and embodiment. This multi-layered analysis challenges the neoliberal ideology prevalent in contemporary media. And if neoliberalism is a form of neocolonialism, this paper constitutes an exercise in decoding/decolonizing representations and performances in contemporary Africa.

I attempt to cultivate a notion of agency not predicated on whether actors determine outcomes of situations. An agential person or group engages in meaningful work and struggles, and makes complicated choices while knowing their constraints. Melaku recognizes that there are things that 'we cannot control' (Interview 2016). Agency is always limited by structures, but agency also becomes possible when we see the workings of structures. Melaku's agency 'dances' around a paradox: he is agential so far as he is able to see his place in history and understand his constraints: land consolidation by big developers, arbitrary state regulations, and society's reluctance to reward arts and artists.

The myth of neoliberal individualism feeds upon stories such as Melaku's, but its devouring is incomplete. Neoliberalism is about freedom made possible through participation in market economy. Human flourishing, however, entails much more than our ability to buy and sell our labor and its products. I know another kind of freedom as a dancer: At times when you dance yourself past exhaustion, you feel that you could dance on forever. You are in love with the Universe, and nothing else matters. A virtuosic dancer, Melaku is familiar with embodied freedom in dance - unfettered by ideology and economics, however ephemerally. Dance rescued him from the street, propelled him onto the international stage, and shaped his entrepreneurial trajectory. Entrepreneurship has constrained Melaku's artistic freedom, but in a neoliberal economy, it is what keeps dance and dancers alive. For sociologists, it's blasphemous to utter 'unfettered' and 'freedom' in one breath. For dancers, those fleeting moments of joyful communion are to live for. And for journalists, visceral sensations may be difficult to discern and capture. It might serve us all very well to acknowledge that human agency has interconnected and contradictory dimensions that elude our disciplinary and institutional hubris. 


\section{Note}

1. Per Ethiopian custom to refer to people by their first names when full names are not used, I use "Melaku" or "Melaku Belay" throughout the paper. I also follow the Ethiopian convention in citing Ethiopian authors, using their first names in short.

\section{Acknowledgement}

While I claim full responsibility for the views presented here, I would like to thank Melaku Belay for helping me locate data sources and reading drafts of this paper, Erika Busse for offering feedback on an early draft, and Amy Hamlin for editing and commenting on a later draft. Thanks to all for the moral support! Please direct all inquiries to hnwilcox@stkate.edu.

\section{Disclosure statement}

No potential conflict of interest was reported by the author.

\section{References}

Asfaw, Haewon. 2015. "Preserving the Old amidst the New: Saving Azmari Bets in Modern Addis Ababa." The Eminence Magazine, July 22.

"Astounding Azmari Bet Strikes." 2009. Addis Fortune. http://melakubelay.com/press, retrieved February 14, 2018.

Bail, Christopher. 2012. "The Fringe Effect: Civil Society Organizations and the Evolution of Media Discourse About Islam since the September 11th Attacks." American Sociological Review 77 (6): 855-879.

Barthes, Roland. 1991 (1957). Mythologies. New York: The Noonday Press.

Bhabha, Homi K. 1997. "The Other Question: The Stereotype and Colonial Discourse." In TwentiethCentury Literary Theory, edited by K. M. Newton, 293-301. London: Palgrave.

"Building Bridges: The Potential of Making the Contemporary Move through Traditions." 2012. Addis Rumble. Accessed January 6, 2017. http://addisrumble.com/?p=672.

Counterfnord. 2007. "December 20th, 2007: The Ex with Getatchew Mekuria / Le Tigre des Platanes / Melaku Belay." Accessed January 6, 2017. https://counterfnord.wordpress.com/tag/getatchewmekuria/.

Doruzka, Petr. 2010. "Festival of Ethiopian Music." Accessed January 7, 2017. http://world.freemusic. cz/index.php/festival-des-musiques-dethiopie-neokazaly-puvab-africkeho-undergroundu/.

Doyle, Rachel. 2014. "In Ethiopia's Capital, A Resurgent Jazz Scene." The New York Times, November 13.

Drewal, Margaret Thompson. 1991. "The State of Research on Performance in Africa." African Studies Review 34 (3): 1-64.

Ferguson, James. 2006. Global Shadows: Africa in the Neoliberal World Order. Durham, NC: Duke University Press.

Gamson, William, David Croteau, William Hoynes, and Theodore Sasson. 1992. "Media Images and the Social Construction of Reality." Annual Review of Sociology 18: 373-393.

Getahun, Solomon. 2007. The History of Ethiopian Immigrants and Refugees in America, 1900-2000: Patterns of Migration, Survival, and Adjustment. New York: LFB Scholarly Pub.

Giorgis, Elizabeth W. 2012. "The Beginning of Ethiopian Modernism: A Brief Synopsis on the Inception of Ethiopian Visual Modernism (1957-1974)." In What is "Zemenawinet"? - Perspectives on Ethiopian Modernity, edited by Elizabeth Giorgis, 60-76. Addis Ababa: Friedrich-Ebert-Stiftung.

Gordon, Oliver. 2016. "Notes from Ethiopia: The Jazz Revival in Addis Ababa." The Guardian, April 1. Harrison, Graham. 2010. Neoliberal Africa: The Impact of Global Social Engineering. London: Zed Books. Heinonen, Paula. 2011. Youth Gangs \& Street Children: Culture, Nurture and Masculinity in Ethiopia. New York: Berghahn Books. 
"Impromptu Addis: A Cinematic Portrait of Samuel Yirga and Melaku Belay." Addis Rumble, December 10, 2013. Accessed January 6, 2017. http://addisrumble.com/? $\mathrm{p}=3840$

Keim, Curtis. 2009. Mistaking Africa: Curiosities and Inventions of the American Mind. Boulder, CO: Westview Press.

Kifetew, Konjit. 2006. "Gender and Cross-Cultural Dynamics in Ethiopia." Agenda: Empowering Women for Gender Equity 68: 122-127.

MaCaulay, Alastair. 2011. "When Feet, Beat and Joy All Soar Funkily." Dance Review, The New York Times, August 12.

Mains, Daniel. 2012. Hope Is Cut: Youth, Unemployment, and the Future in Urban Ethiopia. Philadelphia, PA: Temple University Press.

"Meet Melaku Belay: The Man at Fendika Azmari Bet." ETV interview, 2013. Accessed February 14, 2018. https://www.youtube.com/watch?v=uz3JvG5eNLo

Mehretu, Assefa. 2012. "Ethnic Federalism and Its Potential to Dismember the Ethiopian State." Progress in Development Studies 12 (2 \& 3): 113-133.

Mills, Sarah. 1997 (2004). Discourse. New York, NY: Routledge.

Nieuwenhuys, Olga. 2001. "By the Sweat of Their Brow? 'Street Children,' NGOs and Children's Rights in Addis Ababa." Africa: Journal of the International African Institute 71 (4): 539-557.

Pankhurst, Alula. 1992. Resettlement and Famine in Ethiopia: The Villagers' Experience. Manchester: Manchester University Press.

Poluha, Eva. ed. n.d. The World of Girls and Boys in Rural and Urban Ethiopia. Addis Ababa: Forum for Social Studies.

Romero, Angel. 2015. "Interview with Melaku Belay of Ethiopian Band Fendika." World Music Central. Accessed January 6, 2017. http://worldmusiccentral.org/2015/12/29/interview-with-melaku-belayof-ethiopian-band-fendika/.

Said, Edward. 1994 (1978). Orientalism. New York: Vintage Books.

Smith, Lahra. 2013. Making Citizens in Africa: Ethnicity, Gender, and National Identity in Ethiopia. Cambridge: Cambridge University Press.

Sorenson, John. 1993. Imagining Ethiopia: Struggles for History and Identity in the Horn of Africa. New Brunswick, NJ: Rutgers University Press.

Steeves, H. Leslie. 2016. "Cartographies of Communication and Critique: Forging a Dialogue on Africa, Media, and Globalization." Communication, Culture \& Critique 9: 1-10.

Turton, David. 2006. Ethnic Federalism: The Ethiopian Experience in Comparative Perspective. Oxford: James Currey.

“Under African Skies: Ethiopia." BBC TV 1984. Accessed February 14, 2018. https://www.youtube.com/ watch?v=uz3JvG5eNLo.

"Watch Melaku and Zinash at Africolor 2010." Le Point. Accessed January 5, 2017. http://afrique. lepoint.fr/culture/musique-maestro-melaku-belay-une-icone-ethiopienne-11-08-2014-1860498_ 2256.php.

Weiner, Melissa. 2016. "Colonized Curriculum: Racializing of Africa and Africans in Dutch Primary School History Textbooks." Sociology of Race and Ethnicity 2 (4): 450-465.

Zahorik, Jan. 2011. "Ethnicity and Nationalism in Ethiopia: Some Recent Reflections." The Annual of Language \& Politics and Politics of Identity V: 91-108. 